Research Note

\title{
Homogenization of the Soil Surface Following Fire in Semiarid Grasslands
}

\author{
Carleton S. White \\ Author is Research Associate Professor, Biology Department, MSC03 2020, 1 University of New Mexico, Albuquerque, \\ NM 87131-0001, USA.
}

\begin{abstract}
Semiarid grasslands accumulate soil beneath plant "islands" that are raised above bare interspaces. This fine-scale variation in microtopographic relief is plant-induced and is increased with shrub establishment. Research found that fire-induced water repellency enhanced local-scale soil erosion that reduced variation in microtopographic relief, suggesting that fire may counteract vegetation-driven, fine-scale spatial soil heterogeneity. This article analyzes longer-term measurements (up to 9 yr) of soil microtopography to evaluate the hypothesis that fire in semiarid grasslands results in more homogenous soil microtopographic relief. Changes in soil microtopographic relief were measured prior to and following a total of five fires at three semiarid grasslands within central New Mexico, United States. The fires included three cool-season prescribed fires, a warm-season prescribed fire, and a warm-season wildfire. Four of the five fires resulted in significantly lower soil microtopographic variation that persisted for up to $4 \mathrm{yr}$. The duration and magnitude of the soil leveling effect was lowest in the grassland with clay-rich soils, indicating a possible soil texture interaction. Although two grasslands had net soil loss following fires, no net erosion occurred at the third grassland, indicating that redistribution of soils can occur without net erosion. These results show that management with prescribed fire reduces biotic-driven variation in soil microtopographic relief in semiarid grasslands that may help limit the transition to shrubland ecosystems in this region.
\end{abstract}

\section{Resumen}

Los pastizales semiáridos acumulan suelo debajo de "islas" de vegetación que están elevadas sobre los espacios de suelo desnudo entre las plantas. Esta variación a escala fina en el relieve microtopográfico está inducida por las plantas mismas y se acentúa con el establecimiento de arbustos. Se ha demostrado que las condiciones de hidrofobia inducidas por el fuego acentúan la erosión del suelo a escala local reduciendo la variación en el relieve microtopográfico, hecho que sugiriere que el fuego podría contrarrestar la heterogeneidad de escala fina del suelo generada por la vegetación. Este artículo analiza mediciones de más largo plazo (hasta 9 años) de microfotografía del suelo para evaluar la hipótesis de que el fuego en pastizales semiáridos induce una mayor homogeneidad en el relieve microtopográfico del suelo. Se midieron cambios en el relieve microtopográfico del suelo antes y después de un total de cinco fuegos en tres pastizales semiáridos del centro de Nuevo México, EE.UU. Los fuegos incluyeron tres quemas controladas durante la estación templada, una quema controlada durante la estación cálida, y un incendio ocurrido durante la estación cálida. Cuatro de los 5 fuegos resultaron en variaciones microtopográficas del suelo significativamente menores que persistieron hasta 4 años. La duración y la magnitud del efecto de nivelación fue más bajo en el pastizal con suelos ricos en arcillas, lo que indica una posible interacción con la textura del suelo. Aunque dos de los pastizales tuvieron una pérdida neta de suelo después de los fuegos, no hubo erosión neta en el tercer pastizal, lo que indica que la redistribución de suelo puede ocurrir sin que ocurra erosión neta del mismo. Estos resultados demuestran que el manejo de pastizales semiáridos con fuego prescripto reduce la variación en la microtopografía del suelo generada por los factores bióticos y que dicho efecto podría limitar las transiciones hacia ecosistemas dominados por arbustos en la región.

Key Words: grama grass, creosotebush, broom snakeweed, soil microtopographic relief, soil bridge, erosion

\section{INTRODUCTION}

Semiarid grasslands of the southwestern United States have fine-scale patchy distribution of grasses and shrubs, which creates soil microtopographic features of raised "islands"

\footnotetext{
Research was funded in part by the USDA Forest Service Rocky Mountain Research Station; the National Science Foundation (BSR 88-11906, DEB 9411976, DEB 0080529, DEB 0217774 [Long-Term Ecological Research]); the Sevilleta National Wildlife Refuge; the Cibola National Forest-Sandia Ranger District; and numerous agencies that were involved in conducting the prescribed fires at Bernalillo Watershed and West Mesa.

Correspondence: Carleton S. White, Biology Department, MSC03 2020, 1 University of New Mexico, Albuquerque, NM 87131-0001, USA. Email: cswhite@sevilleta.unm.edu
}

Manuscript received 14 December 2010; manuscript accepted 29 March 2011. beneath plants and lower soil surfaces in between-plant interspaces (Hook et al. 1991; Martinez-Turanzas et al. 1997). Soil islands beneath grasses are raised $3 \mathrm{~cm}$ to $7 \mathrm{~cm}$ or more above the interspace surfaces, and development of greater microtopographic relief is directly related to greater plantinduced resource heterogeneity (Burke et al. 1999; Epstein et al. 2001). Encroachment of woody plants into semiarid grasslands occurred during the last century (Buffington and Herbel 1965; Grover and Musick 1990; Schlesinger et al. 1990). Redistribution of soils to shrub islands is thought to result from interacting processes that, once started, can be self-sustaining and lead to desertification (Schlesinger et al. 1990; Archer et al. 1995; Turnbull et al. 2010). However, Ravi et al. (2009) found that fire resulted in short-term redistribution of soil particles 
Table 1. Descriptions and characteristics of research areas.

\begin{tabular}{|c|c|c|c|}
\hline Site characteristic (units) & Sevilleta & Bernalillo Watershed & West Mesa \\
\hline Latitude/longitude & lat $34^{\circ} 20^{\prime} \mathrm{N}$, long $106^{\circ} 41^{\prime} \mathrm{W}$ & lat $35^{\circ} 17^{\prime} \mathrm{N}$, long $106^{\circ} 30^{\prime} \mathrm{W}$ & lat $35^{\circ} 09^{\prime} \mathrm{N}$, long $106^{\circ} 51^{\prime} \mathrm{W}$ \\
\hline Elevation (m) & 1628 & 1690 & 1830 \\
\hline Aspect & $\mathrm{Na}^{1}$ (flat) & WNW & $\mathrm{E}$ \\
\hline Slope $(\%)$ & $<1 \%$ & $3.9 \%$ & $3.7 \%$ \\
\hline Texture (sand/silt/clay \%) & $68 / 22 / 10$ & $43 / 25 / 32$ & $62 / 10 / 28$ \\
\hline Soil texture class & Sandy Loam & Clay Loam & Sandy Clay Loam \\
\hline Average annual precipitation (mm) & 250 & 270 & 270 \\
\hline Year of livestock exclusion & 1973 & 1947 & early 1970 s \\
\hline $\begin{array}{l}\text { Vegetative community/ } \\
\text { transition community }\end{array}$ & $\begin{array}{l}\text { Great Plains Grassland/ } \\
\text { Chihuahuan Desert }\end{array}$ & $\begin{array}{l}\text { Plains-Mesa Grassland/Juniper } \\
\text { Woodland }\end{array}$ & $\begin{array}{l}\text { Desert Grassland/Colorado Plateau Shrub- } \\
\text { Steppe }\end{array}$ \\
\hline $\begin{array}{l}\text { Grass species by relative } \\
\text { abundance }\end{array}$ & $\begin{array}{l}\text { Bouteloua eriopoda (Torr.) Torr. } \\
\text { Sporobolus sp. } \\
\text { B. gracilis (Willd. ex Kunth) } \\
\text { Lag. ex Griffiths } \\
\text { Pleuraphis jamesii Torr. } \\
\text { Muhlenbergia arenicola Buckl. } \\
\text { Scleropogon brevifolius } \text { Phil. }\end{array}$ & $\begin{array}{l}\text { B. eriopoda (Torr.) Torr. } \\
\text { Bouteloua gracilis (Willd. ex Kunth) } \\
\text { Lag. ex Griffiths } \\
\text { Bouteloua curtipendula (Michx.) Torr. } \\
\text { Aristida purpurea Nutt. } \\
\text { P. jamesii Torr. } \\
\text { Sporobolus sp. }\end{array}$ & $\begin{array}{l}\text { Achnatherum hymenoides (Roemer \& } \\
\quad \text { J.A. Schultes) Barkworth } \\
\text { Hesperostipa comata (Trin. \& Rupr.) } \\
\quad \text { Barkworth } \\
\text { A. purpurea Nutt. } \\
\text { P. jamesii Torr. } \\
\text { B. eriopoda (Torr.) Torr. } \\
\text { Sporobolus sp. }\end{array}$ \\
\hline $\begin{array}{l}\text { Shrubs/trees/others by } \\
\text { relative abundance }\end{array}$ & $\begin{array}{l}\text { Gutierrezia sarothrae } \\
\text { (Pursh) Britt. \& Rusby } \\
\text { Ephedra torreyana S. Wats. } \\
\text { Larrea tridentate (Sessé \& Moc. } \\
\text { ex DC.) Coville } \\
\text { Yucca glauca Nutt. }\end{array}$ & $\begin{array}{l}\text { G. sarothrae (Pursh) Britt. \& Rusby } \\
\text { Juniperus monosperma (Engelm.) Sarg. } \\
\text { A. canescens (Pursh) Nutt. }\end{array}$ & $\begin{array}{l}\text { G. sarothrae (Pursh) Britt. \& Rusby } \\
\text { Atriplex canescens (Pursh) Nutt. } \\
\text { Krascheninnikovia lanata (Pursh) A.D.J. } \\
\quad \text { Meeuse \& Smit } \\
\text { Artemisia filifolia Torr. } \\
\text { J. monosperma (Engelm.) Sarg. }\end{array}$ \\
\hline No. of soil bridges & 5 treatment, 5 control & $\begin{array}{l}16 \text { treatment, } 16 \text { control (12 control } \\
\text { after January 1998) }\end{array}$ & $\begin{array}{l}8 \text { treatment, } 8 \text { control; after } 20018 \text { once- } \\
\text { burned, } 8 \text { twice-burned }\end{array}$ \\
\hline
\end{tabular}

${ }^{1}$ na, not applicable.

and nutrients from shrub islands to lower bare interspaces within a grassland recently invaded by creosote bush (Larea tridentata). Fire-induced water repellency promoted the redistribution of soil particles and created more homogeneous microtopographic relief (Ravi et al. 2009).

Ravi et al. (2010) proposed a conceptual model of island dynamics that highlights fire's ability to enhance the redistribution of soil resources, thereby contributing to the reversibility of the early stages of shrub encroachment. Ravi et al. (2009; 2010) acknowledged that responses of shrub-encroached grasslands to fires could depend on several factors including shrub species, fire intensity and duration, postfire soil moisture conditions, and grazing management. They recognized that additional studies in other rangeland systems were necessary to investigate the general applicability of their model.

Multiple-year measurements of soil microtopographic relief, which used identical methods of Ravi et al. (2009), were used to evaluate the effect of both prescribed fires and a wildfire on net soil erosion in two semiarid grasslands (White and Loftin 2000; White et al. 2006). Microtopographic relief also is being measured by the same method during an ongoing long-term study of a prescribed fire in an additional semiarid grassland that is located about $3 \mathrm{~km}$ from the area used by Ravi et al. $(2009 ; 2010)$. This article evaluates the change in variation of microtopographic relief from these longer-term empirical studies to test the hypothesis that fire in semiarid grasslands results in more homogenous soil microtopographic surfaces.

\section{MATERIALS AND METHODS}

\section{Study Areas}

Study areas established in 1994 and 1995 at three semiarid grasslands within central New Mexico represented the following potential vegetation transitions (see Table 1 for area characteristics): 1) transition from semiarid grassland to juniper woodland (Bernalillo Watershed [BW]); 2) transition from semiarid grassland to Colorado Plateau Shrub-Steppe (West Mesa [WM]); and 3) transition from semiarid grassland to creosote bush desert (Sevilleta National Wildlife Refuge [SNWR]). All areas are located within the central portion of the Rio Grande valley in New Mexico and lie within the same climate region (New Mexico Division 05) utilized by the Palmer Drought Index (White et al. 2004)). The SNWR is the location for the study by Ravi et al. (2009) and the Sevilleta Long-Term Ecological Research (LTER) project (http://sev. lternet.edu). Related research on these areas is reported in White and Loftin (2000), White et al. (2004), and White et al. (2006). All areas had domesticated livestock excluded for $20 \mathrm{yr}$ to $30 \mathrm{yr}$ prior to the fires. There was no record of grassland fires at any of the areas while being grazed.

\section{Fire Dates and Conditions}

Changes in soil microtopographic variation following five different fires in the three areas are reported in this study. General climatic conditions throughout the study period (1995 


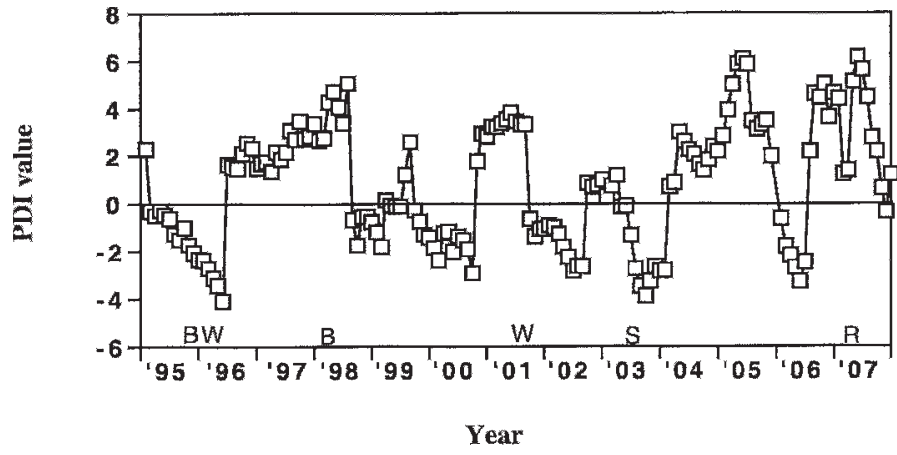

Figure 1. Monthly values of the Palmer Drought Index for New Mexico Division 05 from 1995 to 2008. The 0 line indicates the long-term average for the indicator values. Values of -2 or more negative indicate true "droughts" while increasing positive values represent deviations wetter than the norm. Capital letters represent the approximate time of each of the fires at four research areas (B, Bernalillo Watershed; W, West Mesa; S, Sevilleta; R, study area of Ravi et al. [2009]).

through 2007) and conditions before and after each fire are indicated by the Palmer Drought Index (Fig. 1 [http://www1. ncdc.noaa.gov]). The BW had two cool-season prescribed fires; the first (Fig. 1, B1995, 15 November 1995) was during a drought period and the second (B1998, 28 January 1998) was following a wet period. The WM had two fires; the first (W1996, 14 February 1996) was a cool-season prescribed fire during a drought period and the second (W2001, 13 July 2001) was a warm-season wildfire following a wet period. The WM wildfire burned all treatment and previous control plots. The SNWR prescribed fire (S2003, 20 June 2003) was a warmseason fire during a drought period. The soil bridge sites of Ravi et al. (2009) were burned on 3 April 2007 (Fig. 1, R2007). Microtopography was measured at all areas within 24 to $48 \mathrm{~h}$ of each burn and repeated approximately semi-annually for the indicated periods (see Fig. 2).

Specific conditions for each fire at the $\mathrm{BW}$ and $\mathrm{WM}$ areas were reported in White et al. (2006). The SNWR fire was conducted from 19 through 22 June 2003 with the research plots burned on 20 June. Brief periods of very light rain occurred during the burn period. Conditions during the burn on 20 June were: sustained winds out of the south-southwest at $8 \mathrm{~m} \cdot \mathrm{s}^{-1}$ with gusts to $11 \mathrm{~m} \cdot \mathrm{s}^{-1} ; 17 \%$ relative humidity; air temperature of $32^{\circ} \mathrm{C}$; and average rate of fire spread of $1.3 \mathrm{~m} \cdot \mathrm{s}^{-1}$. Near complete consumption or charring of aboveground vegetation and litter occurred across all five of the locations where the microtopography was measured. Conditions were warm with very light winds during the experimental fires of Ravi et al. (2009, fire conditions not reported).

\section{Soil Microtopography Measurements}

Microtopographic relief was measured with a removable soil bridge that has 31 bushings spaced at $5-\mathrm{cm}$ intervals (White and Loftin 2000; White et al. 2006; Ravi et al. 2009). Each bridge site has two pieces of reinforcement bar that are driven into the soil to a depth of about $40 \mathrm{~cm}$ and fit into holes on the soil bridge so that the bridge was level when in place. The initial heights of individual bridge sites varied. Unlike other soil bridges (Whicker et al. 2002), bridge installation established a

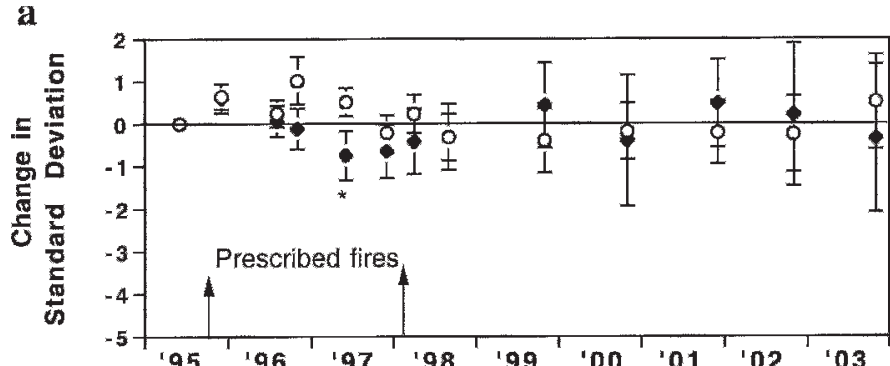

b
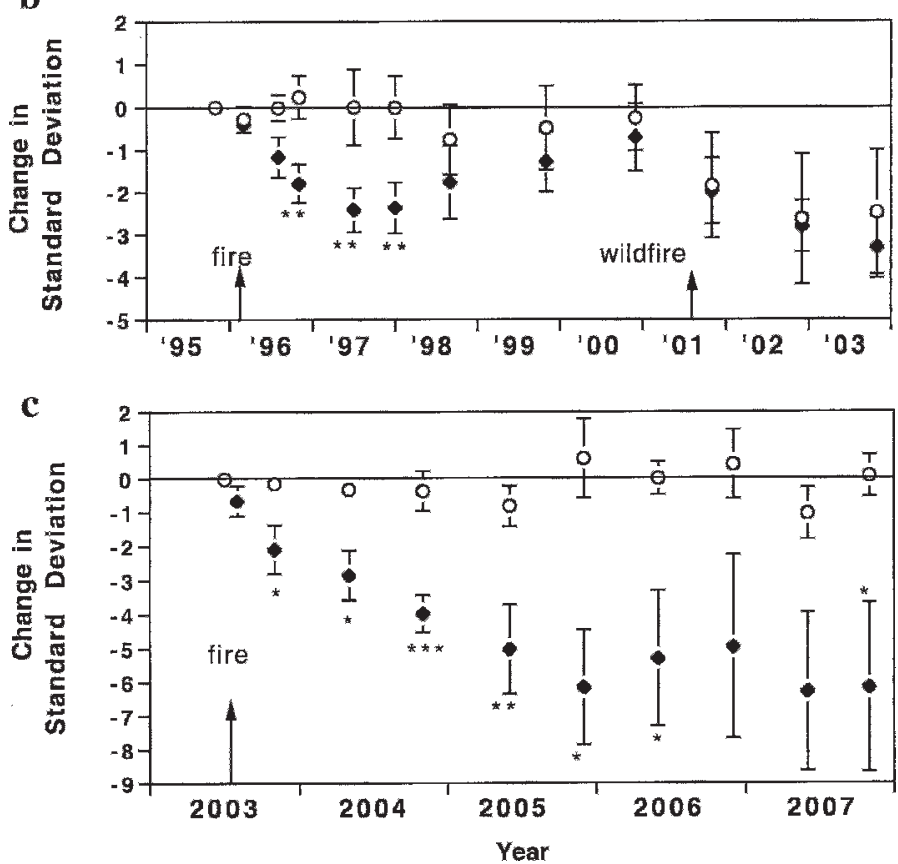

Figure 2. The change over time in the standard deviation of bridge pin measurements for burned (filled symbols $\pm \mathrm{SE}$, fires indicated by arrows) and unburned control (open symbols $\pm \mathrm{SE}$ ) bridges at the Bernalillo Watershed (BW; a), West Mesa (WM; $\mathbf{b}$ ), and Sevilleta National Wildlife Refuge (SNWR; c) research areas. In July 2001 a wildfire burned all WM bridges (b); thus, all subsequent measurements were on burned bridges. Significant differences between the burned and control bridges are indicated by ${ }^{*},{ }^{* *}$, and ${ }^{* *}(P<0.05,0.01$, and 0.001 , respectively $)$.

reference point consisting of a spike that was aligned beneath the middle hole on the bridge and driven flush with the soil so that a measuring pin would rest in a depression in the spike head. At each sampling date, the bridge was mounted on the end bars and the middle reference pin was aligned (heights of the reference pins were either identical to or within $2 \mathrm{~mm}$ of the original height at all bridge sites over the entire study period). Pins were inserted through each bushing to the soil surface, secured with clips if the soil surface was loose, and the portion of each pin extending above the bar was measured. The 30 point profile (reference height excluded) reflects the soil surface microtopography at those points.

The number and placement of soil bridge sites varied between study areas. The SNWR had five burned and five control bridges. The five burned bridge sites were installed in 1994 within an area dominated by Bouteloua eriopoda (Torr.) Torr. (Table 1). In preparation for the prescribed fire, five additional bridge sites were installed in May of 2003 within 
similar vegetation outside of the proposed burn area. This area is part of a long-term study for the Sevilleta LTER (White 1995).

The BW had 16 burned and 16 control bridges. Fire accidentally entered a control area at the BW in 1998, resulting in only 12 control bridges thereafter. The WM study area had eight burned and eight control bridges. The wildfire in 2001 burned all bridge sites, so the original control bridges became once-burned and the burned bridges were twice burned thereafter.

\section{Statistical Analyses}

For each measurement date on each bridge site, the mean and standard deviation (SD) of the 30 height measurements (reference pin height was excluded) was determined. The initial mean height of each bridge site was an arbitrary function of its initial installation, but subsequent changes in mean height indicate net erosion (lower mean height) or soil gain (greater mean height) at each site. The SD of the heights is a direct numerical indicator of heterogeneity of the microtopographic relief. The SD of each bridge on the measurement date before the initial fire treatment served as the reference for all subsequent measurements. The changes in SD on the treated bridges were compared to changes in the untreated bridges on that date to determine the effects of fire-treatment using the nonparametric Mann-Whitney U test. Significant negative change in mean SD following burning was accepted as homogenization of soil microtopography and support for the hypothesis. Unless otherwise indicated, a level of $P \leq 0.05$ was accepted as significant.

\section{RESULTS}

The first prescribed fire at the BW resulted in a lower SD of treated sites relative to the controls $18 \mathrm{mo}$ after the fire, but the second prescribed fire showed no treatment effect (Fig. 2a). At the WM, SD of the fire-treated sites declined following the first fire with significant differences relative to the control after $8 \mathrm{mo}$ that continued for almost $2 \mathrm{yr}$ (Fig. 2b). Following the wildfire at WM, both the twice fire-treated sites and the once-burned control sites showed a sharp decline in SD (Fig. 2b). The three postwildfire measurements of bridges at the once-burned control WM sites had significantly lower SD than the prewildfire collections (Fig. 2b, $P=0.011$ ).

The SNWR fire-treated sites showed a decline in SD with differences between the control and fire-treated areas beginning after $4 \mathrm{mo}$ and continued through the study period (Fig. 2c). The change in mean heights of control and fire-treated bridges were not significantly different and varied little over the study period (mean height change $1.0 \pm 2.1 \mathrm{~mm}$ for controls, $-2.4 \pm 4.6 \mathrm{~mm}$ for treated, $P=0.17$ ), indicating little or no net erosion or gain in soil at both control and burned areas (archived data available; White 1995).

\section{DISCUSSION}

The hypothesis was supported in four of the five fires on the SNWR, WM, and BW (Fig. 2), with the second prescribed fire on the BW the only exception. Note that lowered mean SD does not infer complete homogenization or flattening of the soil surface, which never occurred, but it does indicate reduction of surface heterogeneity. When the results of Ravi et al. (2009) are included (R2007; Fig. 1), five out of six fires in four semiarid grassland locations resulted in homogenization of microtopographic relief that persisted for various time periods. The combinations of multiple fires under different conditions at different locations indicate the relative importance, or lack of importance, of many factors.

Factors associated with the conditions before, during, or after the fire appear relatively unimportant, which was unexpected. Homogenization occurred under a wide range of fire conditions, including cool-season prescribed fires (B2005 and W2006), warm-season prescribed fire (S2003), and summer wildfire (W2001). Similarly, homogenization occurred after fires in drought periods (B1995, W1996, S2003), following wet periods (W2001), and during wetter than normal periods (R2007). These fires had different air temperatures, relative humidity, dew points, soil moisture, fuel loads, rate of fire spread, and wind speed and direction, yet soil microtopographic variation was lowered following each fire.

Factors associated with location had little effect in general. Microtopographic variation was lowered after fires at WM and SNWR even though the locations varied in aspect, slope, and vegetative communities. Soil texture may be a location factor that merits further study. Soils at the BW had the highest clay and silt content (Table 1) and had the lowest change in microtopographic variation following fire (only one collection significant after B1995, none after B1998). Soil texture is known to control various processes in shortgrass steppe (Hook and Burke 2000). Martinez-Turanzas et al. (1997) also found texture to be important for controlling microtopographic relief with sandy soils developing greater relief under undisturbed conditions and fine-textured soil developing greater relief in disturbed areas. Lowered relief following disturbance by fire in the sandy locations (WM and SNWR) and little change in the fine-textured location $(\mathrm{BW})$ is consistent with these other studies.

Other studies have shown greater loss of soil under plant islands relative to bare spaces following fire, but the studies tend to cover short-durations (usually $<1$ yr; Whicker et al. 2002; Ravi et al. 2009). Results from the WM and SNWR show that the duration of effect on soil relief can last $2 \mathrm{yr}$ and longer (Figs. $2 \mathrm{~b}$ and $2 \mathrm{c}$ ). While bridge measurements alone cannot determine the processes that redistribute the soil, factors in addition to the initial fire-induced water repellency could contribute to lowering relief over time periods of $2 \mathrm{yr}$ or more. Both wind and rain surely contributed to the redistribution of soils over the study period, but the relative importance of each process cannot be determined by these data.

\section{MANAGEMENT IMPLICATIONS}

In semiarid grasslands within the southwestern part of the United States, microtopographic relief appears to be the balance of plant-induced heterogeneity and the homogeneityincreasing forces following the removal of plant cover by fire. Reduction in soil microtopographic variation occurred with fires in all seasons and with both prescribed and wildfires. Thus, broad opportunities for altering microtopography may 
exist for management with prescribed fire, which should not impose greater restrictions on safe burning conditions within a fire prescription. However, whether fire is an appropriate management tool to use in any specific grassland will be dependent upon factors other than the potential for altering microtopography.

\section{ACKNOWLEDGMENTS}

Numerous undergraduate and graduate students participated in portions of this work over the years. Doug Moore assisted in collection of soils on the SNWR. Rosemary and Burton Pendleton cooperated on aspects of this research.

\section{LITERATURE CITED}

Archer, S., D. S. Schimel, and E. A. Holland. 1995. Mechanisms of shrubland expansion-land-use, climate or $\mathrm{CO}_{2}$. Climate Change 29:91-99.

Buffington, L. C., and C. H. Herbel. 1965. Vegetation changes on a semidesert grassland range from 1858 to 1963. Ecological Monographs 35:139-164.

Burke, I. C., W. K. Lauenroth, R. Riggle, P. Brannen, B. Madigan, and S. Beard. 1999. Spatial variability of soil properties in the shortgrass steppe: the relative importance of topography, grazing, microsite, and plant species in controlling spatial patterns. Ecosystems 2:422-438.

Epstein, H. E., I. C. Burke, and A. R. Mosier. 2001. Plant effects on nitrogen retention in shortgrass steppe 2 years after ${ }^{15} \mathrm{~N}$ addition. Oecologia 128:422-430.

Grover, H. D., AND H. B. Musick. 1990. Shrubland encroachment in Southern New Mexico, USA: an analysis of desertification processes in the American Southwest. Climate Change 17:305-330.

Hook, P. B., AND I. C. BuRKE. 2000. Biogeochemistry in a shortgrass landscape: control by topography, soil texture, and microclimate. Ecology 81:2686-2703.
Hook, P. B., I. C. Burke, and W. K. Lauenroth. 1991. Heterogeneity of soil and plant $\mathrm{N}$ and $\mathrm{C}$ associated with individual plants and openings in North American shortgrass steppe. Plant and Soil 138:247-256.

Martinez-Turanzas, G. A., D. P. Coffin, and I. C. Burke. 1997. Development of microtopography in a semi-arid grassland: effects of disturbance size and soil texture. Plant and Soil 191:163-171.

Ravi, S., P. D'Odorico, T. E. Huxman, and S. L. Collins. 2010. Interactions between soil erosion processes and fires: implication for the dynamics of fertility islands. Rangeland Ecology \& Management 63:267-274.

Ravi, S., P. D'Odorico, L. Wang, C. S. White, G. S. Okin, S. A. Macko, and S. L. Collins. 2009. Post-fire resource redistribution in desert grasslands: a possible negative feedback on land degradation. Ecosystems 12:434-444.

Schlesinger, W. H., J. F. Reynolds, G. L. Cunningham, L. F. Huenneke, W. M. Jarrell, R. A. Virginia, And W. G. Whitford. 1990. Biological feedbacks in global desertification. Science 247:1043-1048.

Turnbull, L., J. Wainwright, R. E. Brazier, and R. Bol. 2010. Biotic and abiotic changes in ecosystem structure over a shrub-encroachment gradient in the Southwestern USA. Ecosystems 13:1239-1255.

Whicker, J. J., D. D. Breshears, P. T. Wasiolek, T. B. Kirchner, R. A. Tavani, D. A. Schoep, and J. C. Rodgers. 2002. Temporal and spatial variation of episodic wind erosion in unburned and burned semiarid shrubland. Journal of Environmental Quality 31:599-612.

WHITE, C. S. 1995, updated annually. Sevilleta LTER Soil Erosion Bridges and Surface Dynamics 1994-2008. Albuquerque, NM, USA: Sevilleta Long Term Ecological Research Site Database: SEV065, Available at: http://sev.Iternet. edu/project_details.php?id=SEV065. Accessed 11 February 2009.

White, C. S., AND S. R. Loftin. 2000. Response of 2 semiarid grasslands to coolseason prescribed fire. Journal of Range Management 53:52-61.

White, C. S., D. I. Moore, and J. A. Cralg. 2004. Regional-scale drought increases potential soil fertility in semiarid grasslands. Biology and Fertility of Soil 40:73-78.

White, C. S., R. L. Pendleton, and B. K. Pendleton. 2006. Response of two semiarid grasslands to a second fire application. Rangeland Ecology \& Management 59:98-106. 